\title{
慢性肝疾患における血清アスピリンエステラーゼ 活性ならびに血液ガスと肝機能の関係
}

\author{
高野 照夫 \\ 目本㹣科大学第 1 内科学教室（主任: 木村栄一教授)
}

\section{緒言}

アスピリンは古くから解熱㓮, 鎮痛剂として広く使 用され，最近では大量投与療法がリウマチ性疾患に対 して行われている. これに伴い, アスピリンの生体内 代謝に関しても多くの知見が報告され，その分解は主 にアスピリンェステラーゼ(aspirinesterase, 以下 AE と略）によるとされている(

この醳素は生体内に広く分布するが肝において, と くに高い活性が証明され，腎がこれにつぐとされてい $る^{1,2,5,6)}$. Vincent と Parant ${ }^{2)}$ (始めて血清中の AE 活性の動摇を臨床的に観察し, 肝硬変症, 肺結核, 肝 癌で低く, 糖疗病, 高血圧症, 多血症などでは高いこ とを見出し, この活性值の変動は肝機能の 1 指標とし て用いらると述べた。

その後，血清 $\mathrm{AE}$ 活性変動の機転に関する多くの奏 験的, 臨床的研究報告がなされている および荒牧 ${ }^{7}$ は実験的に $\mathrm{AE}$ 活性と肝機能との関連を 検湃し, 肝障害時にはその血清中の活性が低下するこ と, 血清 $\mathrm{AE}$ 活性の低下はアスピリンの代謝能の低 下をきたし，したがって肝障害を一そう助長する可能 性があることを警告した．磯田 ${ }^{12)}$ はうっ血性心不全お よび重症肺結㮎では血清 $\mathrm{AE}$ が低値をとることから， 上記疾患にみられる $\mathrm{AE}$ 活性低下は肝低酸素状態と 関連があることを確めた。

このように，諸種疾患における $\mathrm{AE}$ 活性の動摇に ついての報告は多いが, 他の肝機能検查との関俰を, あるいは血液ガス, 酸塩基平衡状態との関連性などに ついてはほとんど検封されていない。このような観点 から，著者は肝硬変症，慢性肝炎を対象としてその血 清 $\mathrm{AE}$ 活性の動態を再検㶦すると同時に，この䣼素 活性と血液ガス, 酸塩基衡および各種肝機能検査との 関係について臨床的立場からの検討を行なった.

TAKANO, TERUO
研究対象

日本医科大学付属病院第 1 内科入院および外来患者 のうち肝硬変症 42 例（男 36 例，女 6 例, 年令 27 $\sim 74$ 才), 慢性肝炎 40 例 (男 27 例, 女 13 例, 年 令 30 68 才）を対象とした. この中で肝硬変症 31 例，慢性肝炎30 例については血液ガス分析を行な い, 肝硬変症 7 例, 慢性肝炎 18 例については肝生検 を行なった。

上記, 疾患の診断は各種肝機能検查, 肝シンチグラ 么, 肝生検，手術および剖祫所見などによった。

\section{研究方法}

血清 $\mathrm{AE}$ 活性測定のための静脈血および血液ガス 分析のための動脈血は, 原則として早朝空腹時に約 1 時間安静にしたのち, それぞれ时静脈ならびに股動脈 から採血した。

\section{1. 血清 $\mathbf{A E}$ 活性測定法}

酵素活性の測定は荒牧 ${ }^{13)}$ の方法によった. 醅菜活性 はサリチル酸 $1 \mu \mathrm{g}$ を遊離する醭素活性を 1 単位（u） とし, 血清 $1 \mathrm{~m} l$ により 30 分值を以つて示した.

\section{2. 血液カス分析}

動脈血ガス分析には Astrup 装監を用い, 酸素分压 $\left(\mathrm{pO}_{2}\right)$, 炭酸ガス分圧 $\left(\mathrm{pCO}_{2}\right), \mathrm{pH}$ の測定を行ない, 血将の base excess (BE), $\mathrm{HCO}_{3}^{-}$, total $\mathrm{CO}_{2}$ は Siggard-Andersen alignment nomogram により (4), 酸秦飽和度 $\left(\mathrm{SaO}_{2}\right)$ は Astrup が作成した $\mathrm{pO}_{2}$-oxygensaturation $\not 6$ nomogram で計算した.

血液ガスの分析結果の判定は Davenport ${ }^{15)}$ の図, および笹本ら ${ }^{15}$ の作成した標淮值にもとついて行な い, 正常範囲を $\mathrm{pO}_{2} 86 \mathrm{mmHg}$ 以上, $\mathrm{pCO}_{2} 33.5 \sim$ $45.0 \mathrm{mmHg}, \mathrm{pH} 7.35 \sim 7.45, \mathrm{HCO}_{3}{ }^{-} 23 \sim 28 \mathrm{mEq} / \mathrm{L}$, total $\mathrm{CO}_{2} 24 \pm 2, \mathrm{BE}-2.2 \sim+1.2, \mathrm{SaO}_{2} 94.6 \sim$ 
$-42-(42)$

98.7\%とした.

\section{3. 各種肝機能検查}

$\mathrm{AE}$ 測定のため採血したサンプルを用いて行なっ た. 肝機能検査は BSP 45 分值, 黄㾇指数 (II), ZTT, TTT, GOT および GPT (Reitman-Frankel 法, $\mathrm{LDH}$ (Cabaud-Wroblewski 法), アルカリフォスフ エターゼ (Kind-King 法), LAP (Goldbarg 法), ChE (Achorest 法), 血清総蛋白量および蛋白分画である.

\section{4. 肝・脾面掼測定およひ門脈高血圧の測定}

以上の検查とほぼ同時期に $\mathrm{Au}^{138}$ コロイドにより肝 スキャノグラムを行ない，肝および脾の面積を近似的 に測定し, $\mathrm{cm}^{2}$ であらわした. また, 副血行路の程度

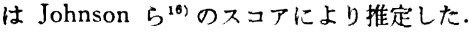

\section{5. 肝生検組織検查}

入院期間中の適当な時期に肝生検を行ない, H-E 染色によりその組織所見を検索した，その変化を炎 症, 壊死, 変性, 再生, 胆汁うつ滞, 線維化の 6 項目 に分け，表 1 に示す個々の所見の有無により，0また は 1 点を与え, 各項目ごとにその和を求め, 病変の評 価を行なったたたたし所見によっては 3 段階にわけ， $0,1,2$ の点数を与えたものもある.

なお，線維化は䏦眏能に与える影響がとくに大と考 えられ，表 1 に示す特別の点数を与えた。

表 1 肝租織所見の採点洼

\begin{tabular}{|c|c|c|c|}
\hline \multicolumn{2}{|l|}{ 炎症 } & \multicolumn{2}{|l|}{ 再生 } \\
\hline グリンン䩪内 & $(2,1,0)^{*}$ & 多核 & $(1,0)$ \\
\hline グリソン鞘内。 & 出血 $(1,0)$ & 核の大小不同 & $(1,0)$ \\
\hline 肝小葉内 & $(1,0)$ & ミトーゼ & $(1,0)$ \\
\hline 限界層の破依 & $(1,0)$ & 風船化細胞 & $(1,0)$ \\
\hline 藻胞形成 & $(1,0)$ & 胆汗うっ湄 & \\
\hline 壊死 & & 胆栓 & $(1,0)$ \\
\hline 好酸体 & $(2,1,0)^{* *}$ & 線維化 & \\
\hline 局所性堆死 & $(1,0)$ & 幅の厈し & 8. \\
\hline 変性 & & 幅の狭い中隔形成 & 6. \\
\hline 脂肪化 & $(2,1,0)^{* * * *}$ & 中等度 & 4. \\
\hline リポフスチン & $(1,0)$ & 軽度 & 2. \\
\hline 空胞㤥 & $(2,1,0)^{* * * *}$ & なし & 0. \\
\hline
\end{tabular}

* 炎症高度の もの 2 点, 軽度のもの 1 点,なし 0 点, ${ }^{* *}$ 好酸 球 1 視野汇 5 個以上 2 点, 5 個未満 1 点, なし 0 点, *** 脂 肪化が 1 個の肝小葉の $1 / 4$ 以上を占めるものを 2 点, それ より軽いむの 1 点, なし 0 点, **** 空胞核各視野ごとにあ るものを 2 点。それより少ないもの1点,なし 0 点

\section{成績}

\section{1. 肝硬変症およひ慢性肝炎における血清AE活性}

肝硬変症における血清 $\mathrm{AE}$ 活性は图 1 に示した。 31 例中 23 例 (74.1\%) が正常値"（左欄）の下限よ り低い值を示し，かつ両者の間に有意の差が証明され た.

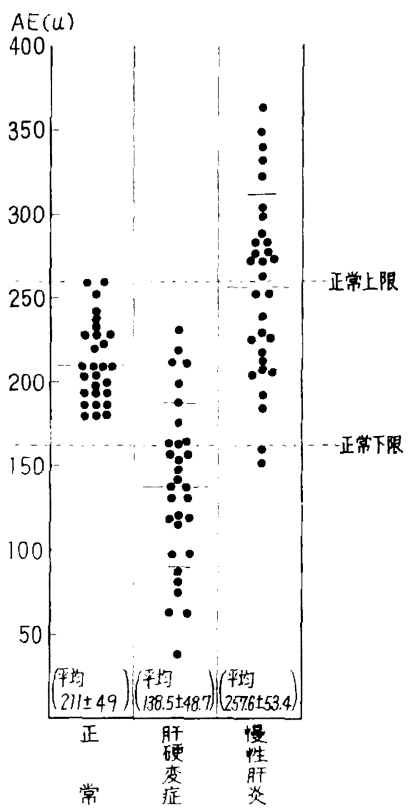

図 1 正常, 肝硬变症, 慢性肝炎に拈ける血清 $\mathrm{AE}$ 活性 正常と䀒硬变症, 正常と慢性肝炎, 䀒 硬変症と慢性肝炎の間にいずれも $p<0.01$ の有意差ある。

慢性肝炎の血清 $\mathrm{AE}$ 活性（図 1) は 31 例中 16 例 (51.6\%) が正常上限を越え, 正常対照に比し有意の 羌 $(p<0.01)$ をもって高い値であった．ただし正常 下限より低い值を示したものが 2 例あった.

したがって肝硬変症と慢性肝炎の間にも有意の差 $(p<0.01)$ があり，前者が低い值を示した.

\section{2. 血清AE活性亡各種肝機能検査値との関係}

肝硬変症では表 2 に示すように，血清 $\mathrm{AE}$ 活性有 意の相関がみられたのは，BSP，ZTT，TTT および $r$ ーグロブリンの各測定值であって、いずれも負の相関 であった。 その他の項目との間には有意の相関は認め られなかった。

他方, 僈性肝炎ではZTTおよび ChE との間に有 意の負の相関が, アルブミンおよび $\alpha_{2}$-グロブリンと の間に有意の正の相関がみられた。その他の項目との 
表 2 畈硬㕠症および慢性肝炎における血消 $\mathrm{AE}$ 活性と各種旰機能の関係

\begin{tabular}{|c|c|c|}
\hline & \multicolumn{2}{|c|}{ 血清 $\mathrm{AE}$ 活性との相関 } \\
\hline & $n$ & $r$ \\
\hline BSP & $\begin{array}{l}27 \\
27\end{array}$ & $\begin{array}{l}-0.546^{* *} \\
-0.131\end{array}$ \\
\hline I.I. & $\begin{array}{l}28 \\
24\end{array}$ & $\begin{array}{l}-0.213 \\
-0.172\end{array}$ \\
\hline ZTT & $\begin{array}{l}31 \\
31\end{array}$ & $\begin{array}{l}-0.502^{* *} \\
-0.452^{* *}\end{array}$ \\
\hline TTT & $\begin{array}{l}30 \\
31\end{array}$ & $\begin{array}{l}-0.448^{*} \\
-0.316\end{array}$ \\
\hline GOT & $\begin{array}{l}31 \\
31\end{array}$ & $\begin{array}{r}-0.151 \\
0.143\end{array}$ \\
\hline GPT & $\begin{array}{l}31 \\
31\end{array}$ & $\begin{array}{r}-0.121 \\
0.096\end{array}$ \\
\hline LDH & $\begin{array}{l}31 \\
31\end{array}$ & $\begin{array}{r}-0.217 \\
0.162\end{array}$ \\
\hline Al-pase & $\begin{array}{l}31 \\
31\end{array}$ & $\begin{array}{l}-0.191 \\
-0.147\end{array}$ \\
\hline LAP & $\begin{array}{l}28 \\
28\end{array}$ & $\begin{array}{r}0.062 \\
-0.130\end{array}$ \\
\hline $\mathrm{ChE}$ & $\begin{array}{l}30 \\
31\end{array}$ & $\begin{array}{l}-0.311 \\
-0.570^{* *}\end{array}$ \\
\hline Total protein & $\begin{array}{l}31 \\
31\end{array}$ & $\begin{array}{r}-0.243 \\
0.084\end{array}$ \\
\hline Albumin & $\begin{array}{l}31 \\
31\end{array}$ & $\begin{array}{l}0.306 \\
0.364^{*}\end{array}$ \\
\hline$\alpha_{1}-G l$ & $\begin{array}{l}31 \\
31\end{array}$ & $\begin{array}{l}0.221 \\
0.076\end{array}$ \\
\hline$\alpha_{2}-G l$ & $\begin{array}{l}31 \\
31\end{array}$ & $\begin{array}{l}0.311 \\
0.463^{* *}\end{array}$ \\
\hline$\beta-\mathrm{Gl}$. & $\begin{array}{l}31 \\
31\end{array}$ & $\begin{array}{l}0.026 \\
0.113\end{array}$ \\
\hline$r-\mathrm{Gl}$. & $\begin{array}{l}31 \\
31\end{array}$ & $\begin{array}{l}-0.567 * * \\
-0.329\end{array}$ \\
\hline
\end{tabular}

上段 : 䀒硬変症, 下段: 慢性肝炎
$* p<0.05, * * 0.01$

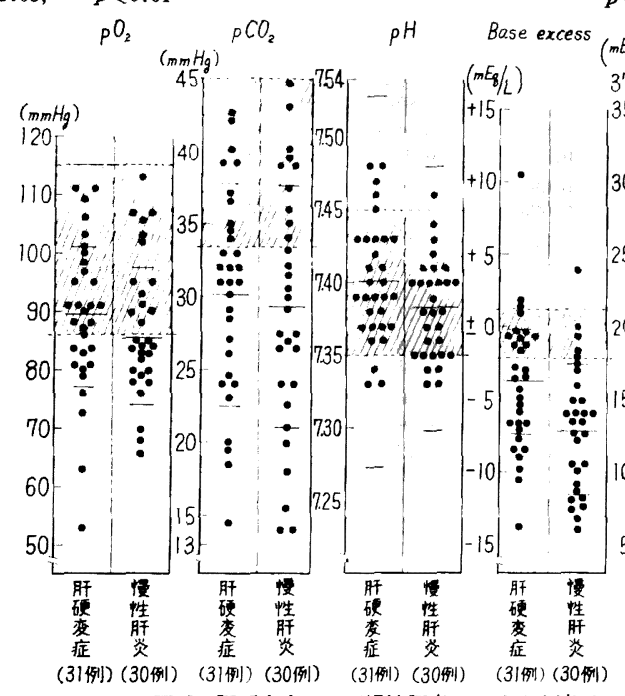

問には有意の相閔はなかった。

\section{3. 血液ガスと血清 $\mathbf{A E}$ 活性の関係}

1) 肝硬変症: 股動脈血の血液ガス分析成績を図 2 に示した. $\mathrm{pO}_{2}$ については, 31 例中 11 例 (35.5\%) が正常下限末満の値を示した. $\mathrm{pCO}_{2}$ はさらに著明な 低下倾向を呈し，21 例（67.79\%）が正常下限より低 い值を示した.しかし， $\mathrm{pH}$ はほぼ正常範囲内にあ り，7.45 を越えるもの 4 例, 7.35 より低いもの 3 例 であった. $\mathrm{BE}, \mathrm{HCO}_{3}$, , total $\mathrm{CO}_{2}$ はいずれも著明 な低下傾向を示し，正常節 囲より低い值がそれぞれ 19 例 (61.2\%), 22 例 (70.9\%), 20 例 (64.5\%) に みられた。しかし， $\mathrm{SaO}_{2}$ は 4 例 (12.79) のみであ

\begin{tabular}{l|c|c}
\multicolumn{2}{c}{ 表 3} & 血清 $\mathrm{AE}$ 活性と血液ガスとの閔係 \\
\hline & $n$ & $r$ \\
\hline $\mathrm{pO}_{2}$ & 31 & $0.432^{*}$ \\
& 30 & 0.068 \\
$\mathrm{pCO}_{2}$ & 31 & -0.109 \\
& 30 & 0.017 \\
$\mathrm{pH}$ & 31 & -0.089 \\
& 30 & -0.129 \\
Base excess & 31 & -0.053 \\
& 30 & -0.009 \\
$\mathrm{HCO}_{\mathbf{3}}-$ & 31 & 0.050 \\
& 30 & 0.001 \\
$\mathrm{Total}^{\mathrm{CO}_{2}}$ & 31 & 0.055 \\
$\mathrm{SaO}_{2}$ & 30 & 0.003 \\
& 31 & $0.429 *$ \\
\hline
\end{tabular}

上段: 肝硬変症, 下段：慢性肝炎

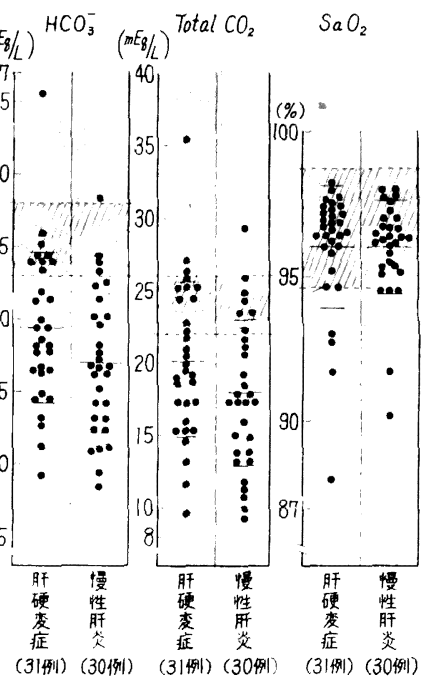

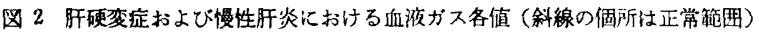


$-44-(44)$

った.

この成績を血清 $\mathrm{AE}$ 活性と比較すると, 表 3 のよ $5 に, \mathrm{pO}_{2}$ および $\mathrm{SaO}_{2}$ との間に有意の正の相関の 存在が示された.

酸塩基平衡については, 表4に示寸上うに呼吸性了 ルカロージスに代䂗性アシドージスの加わった型がも っとも多く，19 例（61.2\%）であった。酸塩基平衡 正常のものは 6 例であった.

なお，酸塩基平衡の所見を血清 $\mathrm{AE}$ 活性と比較し てみたところ、各群ともほぼ同じ血清 $\mathrm{AE}$ 活性を示 し，有意の関倸は認められなかった。

2）慢性肝炎：慢性肝炎について行なった成繶は图 2 に示すごとくで, $\mathrm{pO}_{2}$ は 30 例中 17 例 (56.69) が正常下限より低い值を示し， $\mathrm{pCO}_{2}$ についても20 例 (66.6\%) が正常値より低かった. $\mathrm{pH}$ は大部分正 常籁囲内にあったが, $\mathrm{BE}, \mathrm{HCO}_{3}^{-}$, total $\mathrm{CO}_{2}$ はい ずれも著明な低下傾向を示し，それぞれ 25 例 $(83.3$
$96), 26$ 例 (86.6\%), 23 例 (76.6\%) が正常值より 低い值を呈した. $\mathrm{SaO}_{2}$ が低下を示したのは 5 例 (16.6 タ) であった、ことに $\mathrm{BE}$ は肝硬変症よりもさらに

表 4 肝䃘变症および慢性肝炎における酸㙁基平衡と 各群の组清 $\mathrm{AE}$ 活性の平均值

\begin{tabular}{|c|c|c|c|c|}
\hline & \multicolumn{2}{|r|}{ 肝硬变症 } & \multicolumn{2}{|r|}{ 慢性肝炎 } \\
\hline & 例数 & $\begin{array}{c}\text { 各群の血清 } \\
\mathrm{AE} \text { 活性佃 } \\
(\mathrm{u})\end{array}$ & 例数 & $\begin{array}{c}\begin{array}{c}\text { 各群の血清 } \\
\mathrm{AE} \text { 活性值 } \\
(\mathrm{u})\end{array} \\
\end{array}$ \\
\hline 呼吸性フルカロージス & 4 & $115.0 \pm 26.6$ & & \\
\hline $\begin{array}{l}\text { 呼吸性了ルカロージス } \\
\text { と代謝性フシドージ } \\
\text { の咞存 }\end{array}$ & 19 & $146.7 \pm 46.7$ & 18 & $268.0 \pm 53.7$ \\
\hline $\begin{array}{l}\text { 呼吸性代謝性フルカロ } \\
\text { ーシス }\end{array}$ & 1 & 148 & & \\
\hline 代謝珄アシドーシス & 1 & 117 & 4 & $224.5 \pm 55.6$ \\
\hline $\begin{array}{l}\mathrm{pH} \text { が正常籍用にある } \\
\text { 代铸性了シトーシス }\end{array}$ & & & 3 & $289.3 \pm 42.5$ \\
\hline 正常節囲 & 6 & $130.0 \pm 61.4$ & 5 & $229.4 \pm 31.9$ \\
\hline 計 & 31 & $138.5 \pm 48.7$ & 30 & $258.3 \pm 54.3$ \\
\hline
\end{tabular}

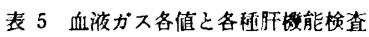

\begin{tabular}{|c|c|c|c|c|c|c|c|}
\hline & $\mathrm{pO}_{2}$ & $\mathrm{SaO}_{2}$ & $\mathrm{pCO}_{2}$ & $\mathrm{pH}$ & $\mathrm{BE}$ & $\mathrm{HCO}_{3}^{-}$ & Total $\mathrm{CO}_{2}$ \\
\hline$A E$ & $\begin{array}{l}0.432^{*} \\
0.068\end{array}$ & $\begin{array}{l}0.429^{*} \\
0.353\end{array}$ & $\begin{array}{r}-0.109 \\
0.017\end{array}$ & $\begin{array}{l}-0.089 \\
-0.129\end{array}$ & $\begin{array}{l}-0.053 \\
-0.009\end{array}$ & $\begin{array}{l}0.050 \\
0.001\end{array}$ & $\begin{array}{l}0.055 \\
0.003\end{array}$ \\
\hline BSP & $\begin{array}{l}0.077 \\
0.219\end{array}$ & $\begin{array}{r}-0.042 \\
0.120\end{array}$ & $\begin{array}{l}-0.072 \\
-0.385^{*}\end{array}$ & $\begin{array}{r}-0.043 \\
0.019\end{array}$ & $\begin{array}{l}-0.078 \\
-0.462^{*}\end{array}$ & $\begin{array}{c}0.025 \\
-0.465^{*}\end{array}$ & $\begin{array}{c}0.004 \\
-0.462^{*}\end{array}$ \\
\hline II & $\begin{array}{c}0.035 \\
-0.381^{*}\end{array}$ & $\begin{array}{c}0.045 \\
-0.618^{*}\end{array}$ & $\begin{array}{l}-0.106 \\
-0.003\end{array}$ & $\begin{array}{r}0.023 \\
-0.174\end{array}$ & $\begin{array}{l}-0.178 \\
-0.094\end{array}$ & $\begin{array}{l}-0.119 \\
-0.05 j\end{array}$ & $\begin{array}{l}-0.140 \\
-0.057\end{array}$ \\
\hline ZTT & $\begin{array}{l}-0.299 \\
-0.138\end{array}$ & $\begin{array}{l}-0.309 \\
-0.257\end{array}$ & $\begin{array}{r}-0.034 \\
0.035\end{array}$ & $\begin{array}{r}-0.266 \\
0.215\end{array}$ & $\begin{array}{l}-0.296 \\
-0.024\end{array}$ & $\begin{array}{l}-0.287 \\
-0.025\end{array}$ & $\begin{array}{l}-0.296 \\
-0.024\end{array}$ \\
\hline TTT & $\begin{array}{l}-0.200 \\
-0.059\end{array}$ & $\begin{array}{l}-0.333 \\
-0.153\end{array}$ & $\begin{array}{l}-0.086 \\
-0.003\end{array}$ & $\begin{array}{l}-0.241 \\
-0.084\end{array}$ & $\begin{array}{l}-0.228 \\
-0.108\end{array}$ & $\begin{array}{l}-0.304 \\
-0.085\end{array}$ & $\begin{array}{l}-0.308 \\
-0.081\end{array}$ \\
\hline GOT & $\begin{array}{r}-0.085 \\
0.284\end{array}$ & $\begin{array}{r}-0.044 \\
0.154\end{array}$ & $\begin{array}{l}-0.077 \\
-0.498^{*}\end{array}$ & $\begin{array}{l}-0.208 \\
-0.125\end{array}$ & $\begin{array}{l}-0.178 \\
-0.447^{*}\end{array}$ & $\begin{array}{l}-0.157 \\
-0.483^{*}\end{array}$ & $\begin{array}{l}-0.152 \\
-0.482^{*}\end{array}$ \\
\hline GPT & $\begin{array}{r}-0.022 \\
0.307\end{array}$ & $\begin{array}{r}-0.113 \\
0.157\end{array}$ & $\begin{array}{l}-0.071 \\
-0.303\end{array}$ & $\begin{array}{l}-0.134 \\
-0.058\end{array}$ & $\begin{array}{l}-0.158 \\
-0.319\end{array}$ & $\begin{array}{l}-0.118 \\
-0.308\end{array}$ & $\begin{array}{l}-0.121 \\
-0.305\end{array}$ \\
\hline LDH & $\begin{array}{r}0.220 \\
-0.090\end{array}$ & $\begin{array}{r}0.158 \\
-0.038\end{array}$ & $\begin{array}{l}0.340 \\
0.317\end{array}$ & $\begin{array}{l}0.359^{*} \\
0.316\end{array}$ & $\begin{array}{r}0.142 \\
-0.006\end{array}$ & $\begin{array}{l}-0.154 \\
-0.092\end{array}$ & $\begin{array}{l}-0.134 \\
-0.010\end{array}$ \\
\hline Al-pase & $\begin{array}{l}-0.001 \\
-0.303\end{array}$ & $\begin{array}{c}0.057 \\
-0.454^{*}\end{array}$ & $\begin{array}{l}-0.090 \\
-0.096\end{array}$ & $\begin{array}{c}0.060 \\
-0.367^{*}\end{array}$ & $\begin{array}{l}-0.015 \\
-0.215\end{array}$ & $\begin{array}{r}0.052 \\
-0.185\end{array}$ & $\begin{array}{r}0.037 \\
-0.181\end{array}$ \\
\hline LAP & $\begin{array}{l}0.002 \\
0.041\end{array}$ & $\begin{array}{l}-0.107 \\
-0.195\end{array}$ & $\begin{array}{l}-0.224 \\
-0.432^{*}\end{array}$ & $\begin{array}{l}-0.008 \\
-0.410^{*}\end{array}$ & $\begin{array}{l}-0.038 \\
-0.602^{* *}\end{array}$ & $\begin{array}{c}0.003 \\
-0.571^{* *}\end{array}$ & $\begin{array}{l}-0.014 \\
-0.569^{* *}\end{array}$ \\
\hline $\mathrm{ChE}$ & $\begin{array}{l}-0.007 \\
-0.012\end{array}$ & $\begin{array}{l}-0.078 \\
-0.196\end{array}$ & $\begin{array}{l}-0.101 \\
-0.061\end{array}$ & $\begin{array}{l}0.233 \\
0.213\end{array}$ & $\begin{array}{l}-0.237 \\
-0.100\end{array}$ & $\begin{array}{l}-0.071 \\
-0.073\end{array}$ & $\begin{array}{l}-0.070 \\
-0.071\end{array}$ \\
\hline 血清総蛋白 & $\begin{array}{l}-0.386^{*} \\
-0.033\end{array}$ & $\begin{array}{r}-0.352 \\
0.015\end{array}$ & $\begin{array}{l}0.044 \\
0.065\end{array}$ & $\begin{array}{l}-0.263 \\
-0.381^{*}\end{array}$ & $\begin{array}{l}-0.086 \\
-0.093\end{array}$ & $\begin{array}{l}-0.262 \\
-0.073\end{array}$ & $\begin{array}{l}-0.258 \\
-0.076\end{array}$ \\
\hline アルブミン & $\begin{array}{r}-0.065 \\
0.034\end{array}$ & $\begin{array}{l}0.029 \\
0.244\end{array}$ & $\begin{array}{l}-0.016 \\
-0.007\end{array}$ & $\begin{array}{l}-0.068 \\
-0.323\end{array}$ & $\begin{array}{l}-0.062 \\
-0.100\end{array}$ & $\begin{array}{l}-0.173 \\
-0.092\end{array}$ & $\begin{array}{l}-0.148 \\
-0.091\end{array}$ \\
\hline$\alpha_{1}$ グロブリン & $\begin{array}{r}0.059 \\
-0.025\end{array}$ & $\begin{array}{r}0.017 \\
-0.057\end{array}$ & $\begin{array}{r}0.010 \\
-0.145\end{array}$ & $\begin{array}{r}-0.270 \\
0.074\end{array}$ & $\begin{array}{l}-0.288 \\
-0.025\end{array}$ & $\begin{array}{l}-0.025 \\
-0.103\end{array}$ & $\begin{array}{l}-0.024 \\
-0.108\end{array}$ \\
\hline$\alpha_{2}$ グロプリン & $\begin{array}{l}0.029 \\
0.320\end{array}$ & $\begin{array}{l}0.155 \\
0.420^{*}\end{array}$ & $\begin{array}{l}-0.012 \\
-0.245\end{array}$ & $\begin{array}{l}-0.016 \\
-0.224\end{array}$ & $\begin{array}{l}-0.029 \\
-0.020\end{array}$ & $\begin{array}{r}0.131 \\
-0.121\end{array}$ & $\begin{array}{r}0.128 \\
-0.124\end{array}$ \\
\hline$\beta$ グロブリン & $\begin{array}{r}-0.204 \\
0.072\end{array}$ & $\begin{array}{r}-0.187 \\
0.233\end{array}$ & $\begin{array}{r}0.101 \\
-0.088\end{array}$ & $\begin{array}{l}-0.377^{*} \\
-0.076\end{array}$ & $\begin{array}{r}0.044 \\
-0.187\end{array}$ & $\begin{array}{l}-0.054 \\
-0.073\end{array}$ & $\begin{array}{l}-0.063 \\
-0.083\end{array}$ \\
\hline ケグロブリン & $\begin{array}{l}-0.297 \\
-0.165\end{array}$ & $\begin{array}{l}-0.375^{*} \\
-0.348\end{array}$ & $\begin{array}{l}0.030 \\
0.145\end{array}$ & $\begin{array}{r}0.005 \\
-0.079\end{array}$ & $\begin{array}{l}0.022 \\
0.018\end{array}$ & $\begin{array}{r}-0.013 \\
0.047\end{array}$ & $\begin{array}{r}-0.037 \\
0.045\end{array}$ \\
\hline
\end{tabular}

上段 : 旰硬变症, 下段：慢性肝资， ${ }^{*} p<0.05,{ }^{* *} p<0.01$

（数字は相関係数を示す） 
低い值をとり, 両者の間に有意の差 $(p<0.05)$ がみ られた。

これら血液ガス分析成績と血清 $\mathrm{AE}$ 活性の相関は, 表了にみられるように, 肝硬変症の場合と異なり，有 意の関保はどの項目についても認められなかった.

つぎに酸塩基平衡については表 4 に示すように, 肝 硬変症におけると同じく, 呼吸性アルカロージスと代 謝性アシドージスをともなった型がもっとも多く，18 例にみられた. なお, 酸塩基平衡と血清 $\mathrm{AE}$ 活性の 間の有意の関倸は見出されなかった。

\section{4. 血液ガス各值と各種肝機能検查の関係}

1）肝硬変症：表 5 に示すよ $5 に, \mathrm{pO}_{2}$ と血清総蛋 白の間に有意の負の相関がみられたが, 他の各種肝機 能検査成續との間には有意の相関がなかった. $\mathrm{SaO}_{2}$ は $\gamma$ ーグロブリンとの間に有意の正の, $\mathrm{pH}$ は $\mathrm{LDH}$ との間に有意の正の, $\boldsymbol{\beta}$-グロブリンとの間に有意の負 の相関を示した. なお, $\mathrm{BE}, \mathrm{HCO}_{3}$ ○よよ゙ total $\mathrm{CO}_{2}$ はいずれの肝機能検查も有意の相関を示さなかっ た.

2）慢性肝炎：表 $\mathbf{5}$ に示すように, $\mathrm{pO}_{2}$ と II との 間に有意の負の相関がみられたが，他の各種所機能検 查との間には有意の相関はなかった. $\mathrm{SaO}_{2}$ は II, ア ルカリフォスフォターゼとの間に有意の負の相関を示 した. $\mathrm{pCO}_{2}$ は $\mathrm{BSP}, \mathrm{LDH}$ および LAP との間に 有意の負の相関を, $\mathrm{pH}$ はアルカリフォスファターゼ および LAP との間に有意の負の相関を示した.さら に $\mathrm{BE}, \mathrm{HCO}_{3}{ }^{-}$, total $\mathrm{CO}_{2}$ の 3 項目は BSP, GOT, LAP の 3 項目の間にそれぞれ有意の負の相関を示し た.

\section{5. 肝の形態学的所見と血清 $\mathbf{A E}$ 活性の関係}

1）肝・脾シンチスキャノグラムによる肝・脾面䅡

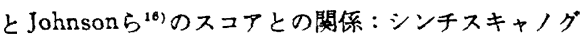
ラムから計測した肝面積は, 肝硬変症も慢性肝炎もほ ほ同し值を示した. しかし, 脾面積については, 肝硬 変症は慢性肝炎より大きな值を呈し, 両者の間に有意 $(p<0.01)$ の差があった. なお, Johnson ら ${ }^{16)}$ のコ アも図3に示すごとく，肝硬変症において有意 $(p<$ 0.01)の差をもって高かった。

肝の面積と血清 $\mathrm{AE}$ 活性の関係は，表 6 に示すよ らに, 肝硬变症, 慢性肝炎いずれの場合も有意の相関 はみられなかった。

また, 肝・脾面積と各種肝機能検查の関係は, 肝硬
$(45)-45-$

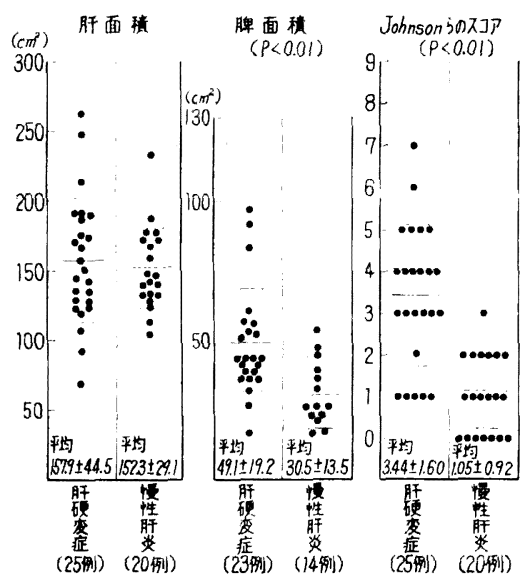

图 3 肝硬変症と慢性肝炎における肝スキャンニング による肝・脾面䅡, Johnson $5^{(0)}$ のスフア

表 6 肝シンチスキャノグラムによる肝・脾面䅪と 各種旰㙨能檢査の関俰

\begin{tabular}{|c|c|c|c|c|c|}
\hline & $\begin{array}{l}\text { 肝面䅡 } \\
\left(\mathrm{cm}^{2}\right)\end{array}$ & $\begin{array}{l}\text { 脾面栍 } \\
\left(\mathrm{cm}^{2}\right)\end{array}$ & & $\begin{array}{l}\text { 肝面積 } \\
\left(\mathrm{cm}^{2}\right)\end{array}$ & $\begin{array}{l}\text { 脾面掼 } \\
\left(\mathrm{cm}^{2}\right)\end{array}$ \\
\hline $\mathrm{AE}$ & $\begin{array}{l}0.211 \\
0.321\end{array}$ & $\begin{array}{r}0.020 \\
-0.094\end{array}$ & 血清総蛋白 & $\begin{array}{l}0.335 \\
0.274\end{array}$ & $\begin{array}{l}0.030 \\
0.386\end{array}$ \\
\hline II & $\begin{array}{l}-0.102 \\
-0.287\end{array}$ & $\begin{array}{l}0.180 \\
0.016\end{array}$ & フルブミン & $\begin{array}{l}0.327 \\
0.338\end{array}$ & $\begin{array}{l}-0.281 \\
-0.284\end{array}$ \\
\hline BSP & $\begin{array}{l}-0.275 \\
-0.045\end{array}$ & $\begin{array}{l}0.380 \\
0.080\end{array}$ & $\alpha_{t} ク ゙ ロ>$ & $\begin{array}{l}0.239 \\
0.291\end{array}$ & $\begin{array}{l}0.200 \\
0.369\end{array}$ \\
\hline $\mathrm{ZTT}$ & $\begin{array}{l}-0.140 \\
-0.136\end{array}$ & $\begin{array}{l}0.162 \\
0.514^{*}\end{array}$ & $\alpha_{2} \not ゙ ロ$ & $\begin{array}{l}0.624^{* *} \\
0.280\end{array}$ & $\begin{array}{l}0.014 \\
0.013\end{array}$ \\
\hline TTT & $\begin{array}{l}-0.090 \\
-0.143\end{array}$ & $\begin{array}{l}0.134 \\
0.330\end{array}$ & $\beta$ グロブリン & $\begin{array}{l}0.761^{* *} \\
0.070\end{array}$ & $\begin{array}{r}0.089 \\
-0.153\end{array}$ \\
\hline GOT & $\begin{array}{r}0.023 \\
-0.040\end{array}$ & $\begin{array}{c}0.043 \\
-0.542 *\end{array}$ & * rグロブリン & $\begin{array}{r}0.374 \\
-0.095\end{array}$ & $\begin{array}{l}0.351 \\
0.377\end{array}$ \\
\hline GPT & $\begin{array}{l}0.003 \\
0.060\end{array}$ & $\begin{array}{l}-0.130 \\
-0.495\end{array}$ & $\mathrm{pH}$ & $\begin{array}{c}0.077 \\
-0.530^{*}\end{array}$ & $\begin{array}{r}0.192 \\
-0.078\end{array}$ \\
\hline LDH & $\begin{array}{l}-0.069 \\
-0.175\end{array}$ & $\begin{array}{l}0.512^{*} \\
0.154\end{array}$ & $\mathrm{pO}_{2}$ & $\begin{array}{r}0.006 \\
-0.131\end{array}$ & $\begin{array}{r}0.124 \\
-0.451\end{array}$ \\
\hline Al-pase & $\begin{array}{l}0.033 \\
0.419\end{array}$ & $\begin{array}{l}0.386 \\
0.342\end{array}$ & $\mathrm{pCO}_{2}$ & $\begin{array}{r}-0.062 \\
0.152\end{array}$ & $\begin{array}{r}-0.351 \\
0.460\end{array}$ \\
\hline LAP & $\begin{array}{l}0.403^{*} \\
0.160\end{array}$ & $\begin{array}{r}0.460^{*} \\
-0.498\end{array}$ & $\mathrm{BE}$ & $\begin{array}{r}0.285 \\
-0.040\end{array}$ & $\begin{array}{l}0.131 \\
0.338\end{array}$ \\
\hline \multirow[t]{3}{*}{ ChE } & $\begin{array}{l}-0.442^{*} \\
-0.320\end{array}$ & $\begin{array}{r}-0.001 \\
0.243\end{array}$ & $\mathrm{HCO}_{8}^{-}$ & $\begin{array}{l}0.184 \\
0.025\end{array}$ & $\begin{array}{l}0.056 \\
0.369\end{array}$ \\
\hline & & & Total $\mathrm{CO}_{2}$ & $\begin{array}{l}0.159 \\
0.036\end{array}$ & $\begin{array}{l}0.006 \\
0.370\end{array}$ \\
\hline & & & $\mathrm{SaC}$ & $\begin{array}{r}0.113 \\
-0.081\end{array}$ & $\begin{array}{r}0.173 \\
-0.262\end{array}$ \\
\hline
\end{tabular}

上段：所硬変症，下段：慢性肝炎， ${ }^{*} p<0.05,{ }^{* *} p<0.01$ （数字は相関係数を示す）

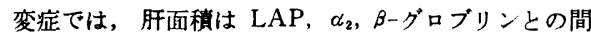
にそれぞれ有意の正の, $\mathrm{ChE}$ との間に有意の負の相 関を示し、脾面積は LDH および LAP との間に有 意の正の相関を示した. 


$$
-46-(46)
$$

慢性肝炎では, 肝面積は $\mathrm{pH}$ との間に有意の負の 相関があり, 脾面積は ZTT との間に有意の正の, GOT との間に有意の負の相関を有した.

Johnson $ら^{16)}$ のスコア5 点以上の場合は副血行路の 存在を示すとされるので， 5 点以上の 6 例と 4 点以下 の19例にわけて, 血清 $\mathrm{AE}$ 活性を含む各種肝機能検 查成績との関係をしらべたが，いずれの項目について も，有意の差は認められなかった.

なお，慢性肝炎で 5 点以上を示した例はなかった。

2) 血清 $\mathrm{AE}$ 活性と肝生検組織像の関倸: 血清 $\mathrm{AE}$ 活 性と肝組織所見の関係をしらべた成績を表 7 に示す.

肝硬変において血清 $\mathrm{AE}$ 活性との間に関係のみら れた肝組織所見は，炎症ならびに壊死であった．他の 所見との間には関倸はなかった. なお, 総合得点と血 清 $\mathrm{AE}$ 活性との閒にも関倸はなかった。

慢性肝炎については, す心゙ての肝組織所見と血清 $\mathrm{AE}$ 活性の間のみならず, 総合得点との間にも関連は なかった.
すでに述べたように, 血清 AE 活性と BSP, ZTT, TTT，テーグロブリンの間に有意の相関がみられ，血 清 AE 活性と線維化の間に密接な 関倸があることが 予測されたのに反し, 肝硬変症においては関倸がえら れなかった。しかし，肝硬変症㧍よび慢性肝炎を併わ せた 25 例につき検討した結果, 血清 $\mathrm{AE}$ 活性の增 加之線維化の進展度，抢よび総合得点の增隇亡の間に も関係がえられた. しかし, 他の組織学的所見の強弱 との間にも関係がみられなかった。

\section{6. 血清 $\mathbf{A E}$ 活性からみた肝硬変症の予後}

血清 $\mathrm{AE}$ 活性測定後 2 年以上の 経過を追跡しえた 肝硬変症 30 例につき, 血清 $\mathrm{AE}$ 活性の推移ならび に予後との関係の検对を行なった. 表8がその結果で ある.

まず血清 $\mathrm{AE}$ 活性と，2 年以上程過したときの生 死の関倸をしらべると, 表 9 のよらに, 血清 $\mathrm{AE}$ 活 性が正常範囲内にあった例に扔ける死亡率にくらべ,

\section{䀒硬变症}

表 7 血声 $\mathrm{AE}$ 活性と旰組織のスコフ

\begin{tabular}{c|c|c|c|ccccccc|c}
\hline No. & 症例 & 年令 & 性 & A E & 壊死 & 再生 & 変性 & 炎症 & 黄㾝 & 線維化 & 総計 \\
\hline 1 & & 67 & 男 & 164 & 1 & 3 & 1 & 2 & 0 & 6 & 13 \\
2 & 27 & 女 & 81 & 2 & 2 & 0 & 5 & 0 & 8 & 17 \\
3 & 69 & 男 & 116 & 2 & 1 & 3 & 3 & 2 & 6 & 17 \\
4 & 44 & 男 & 162 & 0 & 2 & 0 & 1 & 0 & 6 & 9 \\
5 & 43 & 男 & 150 & 1 & 0 & 3 & 2 & 1 & 4 & 11 \\
6 & 38 & 男 & 234 & 1 & 2 & 2 & 1 & 0 & 6 & 12 \\
7 & 56 & 男 & 162 & 0 & 2 & 0 & 1 & 0 & 6 & 9 \\
\hline
\end{tabular}

\begin{tabular}{c|c|c|c|c|ccccccc|c}
\hline \multicolumn{2}{l}{ 慢性肝炎 } \\
\hline No. & 症例 & 年令 & 性 & 分類 & A E & 壊死 & 再生 & 変性 & 炎症 & 黄㾝 & 線維化 & 総計 \\
\hline 1 & 49 & 男 & 2 a & 333 & 1 & 2 & 2 & 3 & 0 & 4 & 12 \\
2 & 36 & 男 & 1 & 341 & 1 & 1 & 3 & 3 & 0 & 0 & 8 \\
3 & 30 & 男 & 2 a & 277 & 1 & 2 & 3 & 3 & 0 & 4 & 13 \\
4 & 56 & 男 & 2 a & 237 & 2 & 1 & 1 & 3 & 0 & 4 & 11 \\
5 & 58 & 女 & 2 a & 237 & 0 & 3 & 3 & 3 & 0 & 2 & 11 \\
6 & 32 & 女 & 2 a & 303 & 3 & 3 & 1 & 2 & 1 & 2 & 12 \\
7 & 30 & 男 & 2 a & 350 & 3 & 1 & 0 & 3 & 0 & 4 & 11 \\
8 & 49 & 女 & 2 a & 290 & 0 & 0 & 1 & 1 & 0 & 4 & 6 \\
9 & 38 & 男 & 2 b & 284 & 2 & 1 & 2 & 2 & 0 & 4 & 11 \\
10 & 37 & 男 & 2 a & 257 & 1 & 0 & 1 & 4 & 0 & 4 & 10 \\
11 & 67 & 男 & 2 a & 240 & 1 & 0 & 2 & 4 & 0 & 4 & 11 \\
12 & 50 & 男 & 2 a & 254 & 0 & 0 & 1 & 4 & 0 & 4 & 9 \\
13 & 44 & 男 & 2 a & 230 & 2 & 0 & 2 & 1 & 1 & 0 & 6 \\
14 & 34 & 男 & 1 & 279 & 0 & 1 & 0 & 1 & 0 & 4 & 6 \\
15 & 58 & 女 & 1 & 279 & 0 & 3 & 0 & 1 & 0 & 2 & 6 \\
16 & 59 & 女 & 1 & 244 & 0 & 2 & 0 & 0 & 0 & 4 & 6 \\
17 & 49 & 女 & 1 & 289 & 0 & 1 & 2 & 1 & 0 & 0 & 4 \\
18 & 56 & 女 & $2 \mathrm{~b}$ & 311 & 1 & 0 & 2 & 4 & 0 & 4 & 11 \\
\hline
\end{tabular}


表 8 肝硬変症における血清 AE 活性の推移

\begin{tabular}{|c|c|c|c|c|c|c|}
\hline No. & 应例 & 年令 & 性 & $\mathrm{AE}$ 值 & $\begin{array}{l}2 \text { 年後の } \\
\mathrm{AE} \text { 值 }\end{array}$ & 死因 \\
\hline 1 & & 67 & 男 & 164 & 57 & \\
\hline 2 & & 27 & 女 & 81 & 112 & \\
\hline 3 & & 69 & 男 & 116 & 96 & 朋性昏埂 \\
\hline 4 & & 44 & 男 & 162 & 130 & \\
\hline 5 & & 73 & 男 & 139 & 77 & \\
\hline 6 & & 48 & 男 & 119 & 121 & 肝性昏挭 \\
\hline 7 & & 50 & 男 & 159 & 176 & \\
\hline 8 & & 46 & 男 & 86 & 137 & \\
\hline 9 & & 57 & 女 & 157 & 278 & \\
\hline 10 & & 45 & 男 & 166 & 269 & \\
\hline 11 & & 64 & 男 & 96 & 151 & 出血死 \\
\hline 12 & & 60 & 男 & 117 & 210 & \\
\hline 13 & & 39 & 男 & 212 & 236 & \\
\hline 14 & & 61 & 男 & 200 & 242 & \\
\hline 15 & & 46 & 男 & 131 & 156 & \\
\hline 16 & & 51 & 男 & 148 & 133 & \\
\hline 17 & & 60 & 男 & 131 & 122 & 出血死 \\
\hline 18 & & 48 & 男 & 189 & 192 & \\
\hline 19 & & 61 & 男 & 176 & 128 & \\
\hline 20 & & 51 & 男 & 141 & & 肝性昏腄 \\
\hline 21 & & 51 & 男 & 220 & & 肝性昏睡 \\
\hline 22 & & 52 & 女 & 231 & & 出血死 \\
\hline 23 & & 60 & 男 & 264 & 209 & \\
\hline 24 & & 56 & 男 & 138 & 106 & \\
\hline 25 & & 71 & 男 & 147 & 112 & \\
\hline 26 & & 53 & 男 & 149 & & 出血死 \\
\hline 27 & & 74 & 女 & 203 & 58 & 出血死 \\
\hline 28 & & 40 & 男 & 231 & 185 & \\
\hline 29 & & 38 & 男 & 300 & 240 & \\
\hline 30 & & 52 & 女 & 165 & 144 & \\
\hline
\end{tabular}

表 9 血清 $\mathrm{AE}$ 活性値からみた旰硬変症の予後 （過去 2 年間以上追跡しえた例）

\begin{tabular}{c|c|cc}
\hline 血清A E活性 $(\mathrm{u})$ & 例数 & 死亡例数 & 死亡帝 $(\%)$ \\
\hline 162 260 & 14 & 3 & 21.4 \\
(正常範囲) & 16 & 6 & 37.5 \\
162 未满 & 30 & 9 & 30.0 \\
\hline 計 & 30.0 \\
\hline
\end{tabular}

異常低值を示した例の死亡率が高かったが, 両者の間 に有意の差は証明されなかった。

つぎに, 2 年以上たって血清 $\mathrm{AE}$ 活性の再検査を行 ないえた例につきしらべると, 表 10 に示すよ5に, 最初異常低值を示した 14 例の5ち, 11 例は 2 年後 も異常值を呈し, 5ち4例が死亡した. しかし, 正常 值へ回復したものが 3 例あった. 初め正常值を示した 12 例では, 5 例が 2 年後異常低値となり, $5 ち 1$ 例が 死亡した. 7 例は依然として正常籁囲の值を示した.
$(47)-47-$

表 10 旰硬変症における血清 $\mathrm{AE}$ 活性の推移

\begin{tabular}{|c|c|c|c|}
\hline & & \multicolumn{2}{|c|}{ 第 2 回検查. } \\
\hline & & 正常値 & 異常低值 \\
\hline \multirow{2}{*}{ 最初の検査 } & $\begin{array}{l}\text { 正常嗔) } \\
\text { (12例) }\end{array}$ & 7 & $5^{*}$ \\
\hline & $\begin{array}{c}\text { 異常低値 } \\
\text { (14例) }\end{array}$ & 3 & $11^{* *}$ \\
\hline
\end{tabular}

\section{考察}

\section{1. 肝硬変症 および懪性肝炎における血清アスピリ} ンエステラーゼ活性

肝硬変症と $\mathrm{AE}$ 活性との関倸についてはすでに Vincent $5^{2)}$, Menguy $5^{5)}$, 日向野卢, 荒牧 ${ }^{7}$, Ecobichon ら"1などの報告がある。いずれも $\mathrm{AE}$ 活 性が低下する結果をえている.

著者の 31 例の肝硬変症における成績もこれらとほ ぼ同様であって, 血清 $\mathrm{AE}$ 活性は, 有意 $(p<0.05)$ の差をもって低く, かつ症例の $74.1 \%$ が正常より低 い值を示した.

一方, 慢性肝炎については荒牧”はその 5 例の血清 $\mathrm{AE}$ 活性を測定し，全例正常箱囲内にあったと報告し ている.

著者は 31 例について再検討を試みたところ正常範 囲のものもあったが, 約半数 (51.9\%) が異常值を示 したことが特徴的であった．低值のものは，2 例にす ぎなかった。

実験的肝障害あるいは肝の部分切除に際して血清 $\mathrm{AE}$ 活性が低下するところから, 血清 $\mathrm{AE}$ の起原は肝 細胞であり,その活性低下は肝細胞の障害, 数の減少 にもとうくものであろらと説明されている5,8).

他方, 磯田 ${ }^{12}$ 沙うっ血性心不全ならびに重症肺結核 患者の血清 $\mathrm{AE}$ 活性がいちじしく低下することを 見出し, 低酸素血症が肝の $\mathrm{AE}$ 産生を障害し, 血清 の AE 活性を低下させるのではないかと考えた.

著者はこの点を臨床的にさらに追求すべく，肝硬変 症における $\mathrm{pO}_{2}$ をしらべた結果，その $35.5 \%$ が正 常值より 低い $\mathrm{pO}_{2}$ 值をとることがわかった．さらに $\mathrm{pO}_{2}$ と血清 $\mathrm{AE}$ 活性の間に有意 $(p<0.05)$ の正の 相関のあることからわかるように, 肝硬変症において は $\mathrm{pO}_{2}$ の低下が血清 $\mathrm{AE}$ 活性低下の要因の 1 つとな っていると䠸えられる。

Boime ら ${ }^{18)}$ は電顕所見にもとづき，低酸素状態の 影響をもっともうけやすいのはミトコンドリアである と述べまた荒牧》は AE は肝細胞内ではミトコン 
$-48-(48)$

ドリア分画にもっとも高い比活性があり，かつ血清 $\mathrm{AE}$ 活性とミトコンドリア $\mathrm{AE}$ 活性の間に有意の相 関のあることを示した。したがって，肝硬変症におけ る AE 活性の低下は動脈血低酸素状態がミトコンドリ アに影響をおよぼした結果であることも考えられる。

肝硬変症がこのような低酸素血症を示すことについ ては, 多くの記载がなされており ${ }^{19 \sim 31)}$, 陲静脈短絡の 存在によると説明されている.

しかし, 慢性肝炎の場合, 動静脈短絡の存在を示す 報告は少なくKravath ら ${ }^{32)}$, Stanley $5^{33)}$ が述べて いるにすぎない, 一方, 著者の結果では, 慢性肝炎に 扔ける低酸素血症の存在は, 肝硬変症よりも高頻度で 観察されたので，慢性肝炎に扔ける $\mathrm{pO}_{2}$ の低下を動 静脈短絡のみで説明することは妥当ではないだうう. この点については今後改めて検討したい.

いずれにしても肝硬変症, 慢性肝炎ともに $\mathrm{pO}_{2}$ の 低下がみられるが，血清 AE 活性は前者では低下し， 後者では上昇を示した，肝疾患時に活性上年をきたす 酳素としてアルカリフォスファターゼが知られてい る34). 慢性肝炎で血清 AE 活性が上昇することが， これと同様の機轱によるか否かは今後の問題である.

なお，このような慢性肝炎と肝硬変症における血清 $\mathrm{AE}$ 活性の差は両疾患の鑑別に役立つと考えられる.

\section{2. 血清 AE 活性と各種肝機能検查の関係}

血清 AE 活性は, 肝硬変症では BSP, ZTT, TTT およびrーグロブリンと, 慢性肝炎では ZTT, アルブ ミンおよび $\alpha_{2}$-グロブリンと，それぞれ正または負の 相関を示した。

市田ら ${ }^{351}$ によると，BSP は肝細胞变性，細胞浸潤 および線維化と，血清 $\boldsymbol{~}$ ーグロブリン值は細胞浸潤お よび線維化と，よく相関するとされ，またPopper ${ }^{36)}$ によれば，血清 $r$ グロブリン值は肝細胞変性ならび に炎症性変化と相関を示すとある.

これらの点からみて, 肝硬変症および慢性肝炎にお ける血清 $\mathrm{AE}$ 活性の変化は, 肝の線維化, 炎症性変 化, 細胞浸潤ないし肝細胞変性に関係を有すると考え てよかろら。

また, 磯田 ${ }^{22}$ は $\mathrm{AE}$ の電気泳動を行ない, $\mathrm{AE}$ 活 性の大部分はアルブミンの領域に, 少量がグロブリン 分画に泳動されるといら結果をえている.したがっ て，慢性肝炎においてみられた血清 $\mathrm{AE}$ 活性とアル ブミンおよび $\alpha_{2}$-グロブリンとの間に相関のあること は,この磯田の結果によって説明されるかも知れな
W.

\section{3. 慢性肝疾患における酸塩基平衡}

著者の成繣において肝硬変症の $67.7 \%$, 慢性肝炎 の $66.6 \%$ が $\mathrm{pCO}_{2}$ の異常低值を示した.

肝硬変症における $\mathrm{PCO}_{2}$ 低下はすでに多くの報告 がある20,25,28,37-38). Vanamee ら ${ }^{38)}$ はアンモニアが呼 吸中权を刺激して，換気量を増大せしめることが原因 であるとしている. Heinemann ら ${ }^{39)}$ も換気量の增大 が $\mathrm{pCO}_{2}$ を低下せしめることを穓察したが，その原 因はわからないと述べている.

慢性肝炎における $\mathrm{pCO}_{2}$ の低下も，すでに Kravath $ら^{32}$ やStanley ら ${ }^{33)}$ により報告されているが，その 発生機序について説明がなされていない。

すなわち, 肝硬変症でも慢性肝炎でも, $\mathrm{pO}_{2}, \mathrm{pCO}_{2}$ 両者ともに低下の傾向を示す.

一方, base excess は, 慢性肝炎では肝硬変症にく らべ，有意の低值を示した。このことは，雨疾患にお ける血液ガスの変化が異なる機序によることを示唆す る.

つぎに酸塩基平衡については, 肝硬変症の $12.8 \%$ で呼吸性アルカロージスがみられたが，これに代賭性 アシドージスの加わった型がそれよりはるかに多く、 $61.3 \%$ を占めた.

Vanamee ら ${ }^{38}$ ) は肝性昏睡 29 例中 25 例(86.2\%) に呼吸性アルカロージスを諗め, Heinemann ら 肝硬変症 11 例中 8 例 (72.796), Snell ${ }^{\circ 0)}$ は 15 例中 6 例 (40.0\%) に呼吸性アルカロージスがみられたと 記載しておう，著者の成結とはかなり異なる.

しかし, Kontos ${ }^{23)}$, Mulhansen ら (1) が報告してい るよらに，肝硬変症では血中乳酸およびピルビン酸量 が増加するであろらから，当然代即性アシドージスの 併存は考えられる. 肝硬変症の場合, 酸塩基平衡がこ のような変化を示すのはおそらくVanamee ら ${ }^{38)}$, あ るいは Heinemann ら ${ }^{39}$ にしたがって説明されるであ ろう.

一方，慢性肝炎における酸塩基平衡についてはこれ まで報告がない，著者の成螋では，呼吸性アルカロー ジスのみを呈したものは 1 例もなかったが, それと代 谢性アシドージスが併存したものが症例の大部分を占 めた.

$\mathrm{pCO}_{2}$ と $\mathrm{BE}$ がともに低值を示したが、このよう な場合，一般的にはどちらかが一次的な変化であり， $\mathrm{pH}$ を正常に保つために他方が代供的に㗢いていると 
考えられる.しかし，肝硬変症の場合と異なり，慢性 肝炎において $\mathrm{pCO}_{2}$ 低下を生ずる一次的な原因を考 えることは困難なのであるから，抒そらく何らかの生 化学的変化によって代暗性アシドージスが一次的に生 し，代㵋的に呼吸性アルカロージスが加わったとする のが妥当であろう.

\section{4. 血液ガス各值と各種䀒機能検查}

1) 動脈血酸素分圧ないし飽和度と各種肝機能検 査: 酸素分圧ないし酸素飽和度と肝機能検查の比較を 行なった研究は少なく、いずれも有意の相関が認めら れなかったとしている(2〜4).

著者の成績では, 肝硬変症においては $\mathrm{pO}_{2}$ と血清 総蛋白の間, $\mathrm{SaO}_{2}$ とテーグロブリンの間に有意の負の 相関がみられた.すでに述べたように, $\mathrm{SaO}_{2}$ と血清 $\mathrm{AE}$ 活性の間, および血清 $\mathrm{AE}$ 活性とrーグロブリン の間に正，あるいは負の有意の相関が観察されたこと からみて, $\mathrm{SaO}_{2}$ とrーグロブリンの間における有意の 相関の存在は，たやすく首肯できるところである。 こ のことは，rーグロブリンが血清 $\mathrm{AE}$ 活性と同じく, 肝のアノキシアの影袈をうけていることを示唆する.

しかし, $\mathrm{pO}_{2}$ が血清総蛋白と有意の負の相関を示し たことは，意外の成績であった. $\mathrm{SaO}_{2}$ とrーグロブリ ンの関倸からみて, $\mathrm{pO}_{2}$ の低いものほど血清総蛋白が 多いということは，でグロブリンの増量によって説明 されるかもしれないが，血清総蛋白の低いもので $\mathrm{pO}_{2}$ が高かったことは，説明できない，

慢性肝炎について $\mathrm{pO}_{2}$ ないし $\mathrm{SaO}_{2}$ と各種肝機能 検査の関係についての報告はまだないと思われるが, 著者の成䋹では $\mathrm{pO}_{2}$ ならびに $\mathrm{SaO}_{2}$ と II ならびア ルカリフォスファターゼの間にそれぞれ有意の負の相 関が， $\mathrm{SaO}_{2}$ と $\alpha_{2}$-グロブリンの間に有意の正の相関 がみられた. 島田ら ${ }^{45}$ はうっ血性心不全において静脈 圧と血清ビリルビン值の間に正の相関があったと述ぺ ている.静脈圧の上昇を直ちに䏦アノキシアにむすび つけることはできないが，慢性肝炎における上記の関 係もこれと共通の因子によって招来されているかも しれない.

$\mathrm{SaO}_{2}$ と $\alpha_{2}$-グロブリンの間にみられた有意の正の 相関については， $\alpha_{2}$-グロブリンが肝で生成されるこ とから，低酸素血症によってその生成が障害されたも のと考えられないでもないが，むしそうなら他の蛋白 分画との間にも相関がみられても良いはずである.こ の問題は今後の検討をまたなければならない。

$$
\text { ( } 49)-49-
$$

2) $\mathrm{pCO}_{2}$, base excess, $\mathrm{HCO}_{3}^{-}$, total $\mathrm{CO}_{2}$ および $\mathrm{pH}$ と各種肝機能㭘查: 肝疾患における $\mathrm{pCO}_{2}, \mathrm{BE}$, $\mathrm{HCO}_{3}{ }^{-}$, total $\mathrm{CO}_{2}, \mathrm{pH}$ と各種肝機能検查の関倸を采 統的にしらべた研究は, 著者の知るかぎりではまだ報 告されていない.

肝硬変症においては, $\mathrm{pH}$ と LDH および $\beta$-グロ ブリンとの間に有意の正の相関が観察され，慢性肝炎 では $\mathrm{pCO}_{2}, \mathrm{BE}, \mathrm{HCO}_{3}^{-}$, total $\mathrm{CO}_{2}$ のおのおのと BSP, GOT, LAP のおのおのとの間に, また $\mathrm{pH}$ と アルカリフォスフォターゼ, LAP ならびに血清総蛋 白との間にそれぞれ有意の負の相関を示した.

以上の関係がいかなる意味を有するかについては, 現在の段階では不明である.

\section{5. 肝の大きさと血清 AE 活性および各種肝機能検} 查

著者は前述のように，肝硬変症における血清 $\mathrm{AE}$ 活 性の低下の機序は, 肝アノキシアと肝組織障害とが加 わったためであると考えられる.

肝硬変症や慢性肝炎において肝細胞数の減少を臨床 的にしらべることは，現段階では不可能である．ただ Yagan ら ${ }^{(6)}$ がシンチグラムにより肝重量を推定する 試みを発表しており, 多少とも肝細胞数に関連ある指 標となりうると考え, シンチグラムによる肝面積を計 った.

その結果は, 肝硬変症では平均 $157.9 \mathrm{~cm}^{2}$, 慢性肝 炎では $152.3 \mathrm{~cm}^{2}$ でほとんど差がなかった. McAfee $5^{47}$, DeLand $5^{(8)}$, 上田 ${ }^{(9)}$ の報告の値から日本 人の肝面積を計算すると, 平均 $124.7 \mathrm{~cm}^{2}$ となる. この值にくらべると, 著者の測定した肝面積は, 両疾 患とも正常よりかなり大きいと推定された.

しかし, これらの肝面積の值と血清 $\mathrm{AE}$ 活性の間 には，両疾患とも有意の相関は見出されなかった。

肝面䄼と各種肝機能検查の関係についてしらべたと ころ, 肝硬変症では LAP， $\alpha_{2}$ および $\beta$-グロブリン との間に有意の 正の, ChE との間に有意の負の相閔 がみられた。このことは, $\mathrm{ChE}$ は肝で生成され ${ }^{\mathrm{s})}$, また $\alpha_{2}$ および $\beta$-グロブリンも肝において作られる ということと関連するであろう.

\section{b. 脾の大きさと各種肝機能検查}

脾面積との間に有意の相関を有したのは，肝硬変症 では LDH および LAP であった. LDH は肝細胞 の壊死を LAP は肝内胆管の変化を反映する検査法と 


$$
-50-(50)
$$

され，一方脾の大きに関与する要因は閒脈圧の亢進で あるから，門脈圧艺進の強いものほど，LDH および LAP が高い值を示すということができる，そのうち $\mathrm{LDH}$ と同様肝細胞の壊死を反映するとされる GOT, GPT と脾面積の間に相関が認められなかった.

慢性肝炎で脾面積との間に有意の相関がみられたの は，ZTTと GOT であった，ZTT は肝の線維化お よび細胞浸潤をよく表現する検查法であるとされる. 肝の線維化が進めば, 当然門脈圧の亢進が生ずるた め, 脾面積と ZTT の間の有意の相関はこれによって 説明される. しかし, 脾面積とGOT の間に有意の負 の相関がみられたことは予想外のことであり，らまい 説明はない。

なお，脾面稹と血清 $\mathrm{AE}$ 活性との間の相関は，両 疾患とも存在しなかった。

\section{Johnson らのスコアよ各種肝機能検査}

Johnson ら"19は, 肝シンチグラムによるスコアが 5 点以上のとき副血行路の存在が考えられるとした.

著者の症例では肝硬変症 25 例中 6 例が 5 点以上の スコアを示したが, 慢性肝炎で 5 点以上のものが 1 例 もなかった.これは当然の成績といってよかろう.

さらに著者は肝硬変症例で 5 点以上の 6 例と 4 点以 下の 19 例に分けて, 各種肝機能検査の比較を行なっ た.しかし, 血清 $\mathrm{AE}$ 活性をふくむすべての項目に ついて有意の差は認められなかった。このことは, 副 血行路の存在は肝機能検査と必ずしも関連を有しない ことを示唆する.

\section{8. 血清 $\mathbf{A E}$ 活性之肝組織像}

血清 AE 活性は肝硬変症ではBSP,ZTT, TTTお よび $r$ グロブリン值と, 僈性肝炎では ZTT, TTT, $\mathrm{ChE}$, アルブミンおよび $\alpha_{2}-$ グロブリンとの間に有意 の正, または負の相関を示した.この結果から，機能 検査のもつ意味からみて, 血清 $\mathrm{AE}$ 活性值は肝の炎 症および線 維化との間に関係のあることが考えられ る.よって肝組織像の変化の強さを表 1 のよ5に点数 として表現し，そのスコアをもって変化の強さとみな して, 血清 $\mathrm{AE}$ 活性との関倸をしらべた.

その結果, 肝硬変症においては壊死および炎症が強 い例で, 血清 AE 活性值が低値をとる傾向をえた. 慢性肝炎ではどの項目についても関連性がなかった。

慢性肝炎において血清 $\mathrm{AE}$ 活性との間に関倸のみ られないのは, 血清 $\mathrm{AE}$ 活性が多くは正常籍用内に
ありしたがって必ずしも炎症の強さとの間に関係が ないからであろう。

\section{9. 血清 $\mathbf{A E}$ 活性からみた肝硬変症の予後}

肝硬変症の予後の判定には各種肝機能検査のうち,

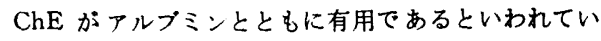
$\Xi^{50)}$.

磯田 ${ }^{12)}$ は心不全の重症度と血清 $\mathrm{AE}$ 活性の比較を 行ない, 重症なものほど低值をとり，かつ心不全が改 善された例では血清 $\mathrm{AE}$ 活性が正常籍囲内に上䄯回 復したのに対し，死亡例ではもどらなかったことか ら, 血清 $\mathrm{AE}$ 活性は心不全の予後判定に有用である とした.

著者が肝硬变症について血清 $\mathrm{AE}$ 活性と予後の関 倸をしらべた結果では，血清 $\mathrm{AE}$ 活性值が異常に低 下した例と正常範囲内にあった例の間に，有意の差は 見出されなかった。 さらに2 年後に血清 $\mathrm{AE}$ 活性の 再検查を行ないえた例についての検討からわかるよ5 に, 最初異常低值を示した例は回復がなかなか困難で あること，最初異常低值を示した例でも，その半数近 くが血清 $\mathrm{AE}$ 活性の低下をきたすことがみられ，本 症は最初の血清 $\mathrm{AE}$ 活性に関係なく, 進行性, 難治 性であることが，改めて認酐された. Vincent ら²の いうよ5に，血清 $\mathrm{AE}$ 活性は肝硬变症の予後判定に 有用であるとは考えがたい。

\section{結論}

慢性肝疾患(肝硬変症, 慢性肝炎) に㧍ける血清 aspirinesterase 活性変動を中心として検索を行ない， 以下の結果をえた.

1）肝硬変症における血清 aspirinesterase 活性は, 正常対照に比し有意の低値を示し，かつ症例の 74.1 \%が正常簀囲より低い值を示した。これは従来の報告 と一致する.

2) 肝硬変症における股動脈血 $\mathrm{pO}_{2}$ は症例の 35.5 96に, 慢性肝炎では 56.696 において低值を示した。

3) 肝硬変症では血清 aspirinesterase 活性と $\mathrm{pO}_{2}$ および $\mathrm{SaO}_{2}$ との間に有意の正の相関がみられた。

4）慢性肝炎における血清 aspirinesterase 活性は 正常対照，および肝硬変症より有意の高值を示し，慢 性肝炎と肝硬変症の鑑別診断に役立つと考えられる.

5）肝硬変症では血清 aspirinesterase 活性と BSP,

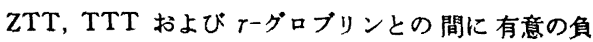
の相関が琶められ，慢性肝炎では血清アルブミンおよ 


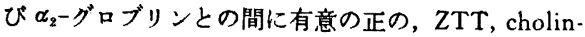
esterase との間に有意の負の相関が梽められた.

6）肝硬変症,慢性肝炎，いずれも症例の大半が低い $\mathrm{pCO}_{2}$ を示した. base excess 仙両疾患とも大部分の 例が正常より低い值を示したが，慢性肝炎における值 は肝硬変症よりもさらに有意の差をもって低かった。

7) 肝硬変症の過半数は呼吸性アルカロージスに代 謝性アシドージスの加わった型を呈した。低酸素血症 が換気量の増大をきたし， $\mathrm{pCO}_{2}$ の低下，呼吸性了ル カロージスを招くと䠸えられる.

8）慢性肝炎でも過半数が呼吸性アルカロージスと 代謝性アシドージスの併存する型を呈した。 base excess の差からみて，その発生機序は肝硬変症とは 異なるものと考えられる.

9）肝硬変症では $\mathrm{pO}_{2}$ と血清総蛋白の間, 酸素飽 和度と rーグロブリンの間に 有意の負の相関が，僈性 肝炎では $\mathrm{pO}_{2}$ ならびに酸素飽和度と黄疽指数ならび にアルカリフォスファターゼの間に有意の負の相関 が, 酸秦飽和度と $\alpha_{2}$-グロブリンの間に有意の正の相 関がみられた。

10) 僈性肝炎では $\mathrm{pCO}_{2}$, base excess, $\mathrm{HCO}_{2}^{-}$, total $\mathrm{CO}_{2}$ のおのおのと BSP, GOT, LAP のおのお のとの間に有意の負の相関がみられた. しかし，肝硬 変症では相関は証明されなかった。

11）血液 $\mathrm{pH}$ は両疾患とも正常籁囲内にある例が 多かったが, 肝硬変症では $\mathrm{LDH}$ および $\beta$-グロブリ ンとの間に有意の正の相関が，慢性肝炎ではアルカリ フォスファターゼ，LAP ならびに血清総蛋白との間 に有意の負の相関がみられた。

12）動脈血酸素飽和度は両疾患とも正常篹囲内に ある例が多かった。

13）シンチグラムから計測した肝面積は，肝硬変 症と慢性肝炎の間で有意の差がなかった，脾面積は慢 性肝炎より肝硬変症で有意の高値を示した，なお，両 疾患ともに肝面積および脾面積と血清 aspirinesterase 活性の間には有意の相関はなかった。

14）肝硬変症では，肝面䅡と LAP， $\alpha_{2}$ および $\beta$ グロブリンとの間に有意の正の, cholinesterase との 間に有意の負の相関があり，慢性肝炎では $\mathrm{pH}$ との間 に有意の負の相関がみられた。

15）肝硬変症では脾面積は LDH および LAP と の間に有意の正の相関を，慢性肝炎ではZTTと有意 の正の, GOT と有意の負の相関を示した.

16) Johnson ら ${ }^{16)}$ のスコアにより肝硬変症 25 例

$$
\text { ( } 51)-51-
$$

中 6 例が副血行路ありと判定されたが，慢性肝炎には 1 例もなかった. 副血行路のある群とない群の間で, 血清 aspirinesterase 活性を含む各種肝機能検查值に 有意の差はみられなかった

17）肝生検組織像については，肝硬変症では炎症 ならび壊死と血清 aspirinesterase 活性との間に関俰 があり，慢性肝炎では関係はなかった．肝硬変症では 准行性のものほど, 血清 aspirinesterase 活性が低值 を示した。

18）肝硬変症において血清 aspirinesterase 活性值 が予後判定の指標となりうるという成績はえられなか った.

本踚文の要旨は、第 57,59 回日本消化器病学会総会、第? 回日本肝睛学会総会において発表した。

\section{女献}

1) Vandelli, I., et Scaltriti, F. : Alcuni organi animali sono ricchi di un fermento, cheè capace di scindere l'acido acetilsalicilico, che non si può indentuficare con la colino esterasi, echeviene ad accrescersi depo strazioni ripetude di aspirina. Bull. Soc. Ital. Biol. Sper., 21, 77, 1943.

2) Bondi, S., und Katz, H. : Studien über die Wirkung der Azetylsalizyläure. Zeits. Klin. Med., 72, $177,1911$.

3) Vincent, D., et Lagreu, R. : L'hydrolyse enzymatique del' acide acetylsalicylique. Bull. Soc. Chim., 31, 216, 1949.

4) Vincent, D., et Parant, M. : L'hydrolyse enzymatique de l'aspirine en clinique. Press. Med., 58, 1030, 1950.

5) Menguy, R., Desbaillets, L., Okabe, S., and Masters, Y.F. : Abnormal aspirin metabolism in patients with cirrhosis and its possible relationship to bleeding in cirrhosis. Ann. Surg., 176, 412, 1972.

6) 日向野晃一: アスビリンエステラーゼと旰矔撜能との 関係. 日医大誌, 24, 295，1957。

7）荒牧椓己：アスピリンによる阶障害にかんする臨床的 ならびに実験的研究．日医大誌，40，344，1973.

8) Mulinos, M.G., and Ardam, I. : An aspirin spilitting enzyme in blood. J. Pharmacol. Exp. Therap., 98, 23, 1950.

9) Beckman, H. : Differential distribution of enzyme hydrolyzing acetylsalicylic acid (aspirin) in certain fluids of the rat. Proc. Soc. Exper. Biol. Med., 93, $144,1956$.

10) Leonards, J.R. : Presence of acetylsalicylic acid in plasma following oral ingestion of aspirin. Proc. Soc. Exper. Biol. Med., 119, 304, 1962.

11) Morgan. A.M., and Truitt, E.B. : Evalution of acetylsalytilic acid esterase in aspirin metabolism. J. Pharm. Sci., 54, 1640, 1965.

12）磯田教二：うっ血性心不全と aspirin esterase 活性. 
日医大跽, 41，1，1974.

13）奥村英正，磯田教二，荒牧珴已，市像，福田显， 酒井義雄：新しい杆蛲能検查としての aspirinesterase 活性. 最新医学, 26, 162, 1971.

14）山村秀夫：酸・㙏基平衡のはかり方とその跈断法. 呼 吸之循環，15,237, 1967.

15）笹本浩，太田保世：血液ガスーその数值をどう繶むか 一. 日本臨床, 27, 175, 1969.

16) Johnson, R.B., Castell, D.O., and Lukash, W.M. Liver scanning for detection of collateral circulation in liver disease. J.A.M.A., 201, 528, 1969.

17) Ecobichon, D.J., and Kalow, W. : Properties and classification of the soluble esterases of human liver. Biochem. Pharmacol., 11, 573, 1963.

18) Boime, I., Smith, E.E., and Hunter, F.E.Jr. : Stability of mitochondria in ischemic rat liver. Arch. Biochem. Biophys., 128, 704, 1968

19) Darling, R.C. : Arterial oxygen saturation in cirrhosis of the liver. Ann. Int. Med., 14, 898, 1940.

20) Rydell, R., and Hoffbauer, W. : Multiple pulmonary arteriovenous fistulas in juvenile cirrhosis. Am. J. Med., 21, 450, 1956.

21) Evans, M.B. : Biliary cirrhosis with cyanosis and fingerclubbing. Proc. Roy. Med., 30, 406, 1037.

22) Rordman, T. : Cyanosis, clubbing and arterial oxygen unsaturation associated with Laennec's cirrhosis. Am. J. Med. Sci., 283, 534, 1959.

23) Kontos, H.A., Shapro, W., Mauck, H.P., and Patterson, J.L. : General and regional circulatory alterations in cirrhosis of the liver. Am. J. Med., 37, 526, 1964

24) Abelman, W.H., Kramer, G.E., Verstraeten, J.M., Gravallese, M.Jr., and McNeely, W.F. : Cirrhosis of the liver and decreased arterial oxygen saturation. Arch. Int. Med., 108, 102, 1961.

25) Bashour, F.A., Miller, W.F., and Champion, C. B. : Pulmonary venoarterial shunting in hepatic cirrhosis. Am. Heart J., 62, 350, 1061.

26) Gamal, M., Stoker, J.B., Spider, E.M., and Whitaker, W. : Cyanosis complicating hepatic cirrhosis. Report of a case due to multiple pulmonary arteriovenous fistulas. Am. J. Card., 25, 49, 1970.

27) Calabresi, P., and Abelman, W.H. : Port-cavel and portpulmonary anastomosis in Laennec's cirrhosis in heart failure. J. Clin. Invest., 36, 1257, 1957.

28) George, J., Mellemgaard, K., Tygstrup, N., and Winkler, K. : Venoarterial shunts in cirrhosis of the liver. Lancet, 1, 852, 1960.

29) Keys, A., and Snell, A.M. : Respiratory properties of the arterial blood in normal man and in patients with disease of the liver, possition of the oxygen dissociation curve. J. Clin. Invest., 17, 58, 1938.

30) Caldwell, P.R.B., Fritts, H.W.Jr., and Cournand, A. : Oxyhemoglobin dissociation curve in liver disease. J. Appl. Physiol., 20, 316, 1965.

31) DaOud, F.S., Reeves, J.T., and Schaefer, J.W.:
Failure of hypoxic pulmonary vasoconstriction in patients with liver cirrhosis. J. Clin. Invest., 51, 1079, 1972.

32) Kravath, R.E., Scarpelli, E.M., and Bernstein, J. : Hepatogenic cyanosis : Arteriovenous shunts in chronic active hepatitis. J. Pediat,, 18, 238, 1971.

33) Stanley, N.N., Achrill, P., and Wood, I. : Lung perfusion scanning in hepatic cirrhosis. Br. Med. J., 16, 639, 1972.

34) Sherlock, S., Walshe, V.: Hepatic alkaline phosphatase, histological and microchemical studies on liver tissue in normal subjects and in liver and bone disease. J. Path. Bact., 59, 615, 1947.

35）市田文弘，在々木博，井上恭一，药岡哲男：畈の生㛟 所見と機能検查. 内科，21，1004，1968.

36) Popper, H., and Schaffner, F. : Liver structure and function. p. 663, McGraw Hill Book Co., New York. Tronto, London, 1957.

37) Rodman, T., Sobel, M., and Close, H.P. : Arterial oxygen unsaturation and the ventilation-perfusion defects of Laennec's cirrhosis. New Engl. J. Med. 263, 73, 1960.

38) Vanamee, P., Poppell, J.W., Gliksman, A.S., Randall, H.T., and Roberts, K.E. : Respiratory alkalosis in heoatic coma. Arch. Int. Med., 37, $762,1956$.

39) Heinemann, H.O., Emirgal, C., and Mijnssen, J.P. : Hyperventilation and arterial hypoxia in cirrhosis of the liver. Am. J. Med., 28, 239, 1960.

40) Snell, R.E. : The relation of arterial hypoxemia to the hyperventilation of chronic liver diseases. Am. J. Med. Sci., 245, 289, 1963.

41) Mulhausen, R., Eichenholz, A., and Blummental, A. : Acid-base disturbance in patients with cirrhosis of the liver. Medicine., 18, 185, 1967.

42）二之宮景光：肝㙨能とアルキシフ，とくに心手術後の 肝障害を中心として。代謝，5，854，1968。

43）原田尚, 香田治男, 岡田了三：心疾愚における肝障 害. 国際肝膰研究会日本支部第 5 回総会諈演, 1963.

44）中村隆，中村省三，金子長次，阿部士郎，田沢悌三， 相川達也，鈴木敏己：46）の追加.

45）鼠田宣浩, 太田康幸, 桶口祥光，木律裕州：心疾患時

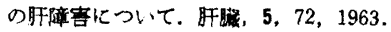

46) Yagan, R., MacIntyre, W.J., and Christie, J.H. : Estimation of liver size by the multiple cut off scintillation scanning technique. Am. J. Roentgen., 88, 296, 1962.

47) McAfee, J.G., Ause, R.G., and Wagner, H.N.Jr. : Diagnostic value of scintillation scanning of the liver. Arch, Intern. Med., 116, 95, 1969.

48) DeLand, F.H., and North, W.A. : Relationship between liver size and body size. Radiology., 91, $1195,1968$.

49）上田英雄: 肝䀣病. 上卷, p. 1, 南江堂, 東京, 1962.

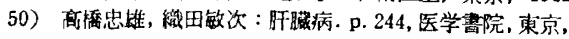
1973.

（受付：1974 年5月18日） 